
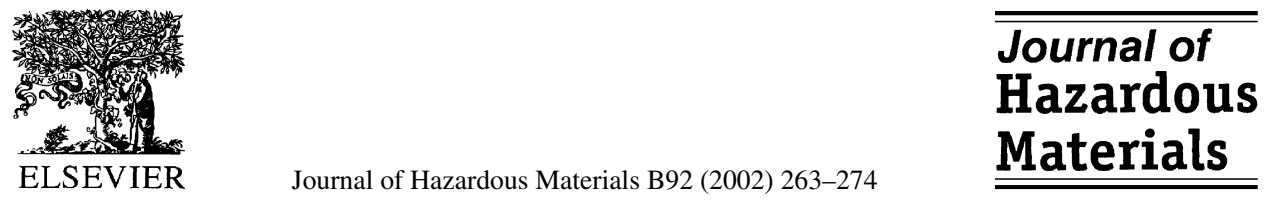

www.elsevier.com/locate/jhazmat

\title{
Use of cellulose-based wastes for adsorption of dyes from aqueous solutions
}

\author{
Gurusamy Annadurai ${ }^{a}$, Ruey-Shin Juang ${ }^{\text {b,* }}$, Duu-Jong Lee ${ }^{\text {a }}$ \\ ${ }^{a}$ Department of Chemical Engineering, National Taiwan University, Taipei 106, Taiwan, ROC \\ ${ }^{\mathrm{b}}$ Department of Chemical Engineering, Yuan Ze University, Chung-Li 320, Taiwan, ROC
}

Received 26 October 2001; received in revised form 16 January 2002; accepted 17 January 2002

\begin{abstract}
Low-cost banana and orange peels were prepared as adsorbents for the adsorption of dyes from aqueous solutions. Dye concentration and $\mathrm{pH}$ were varied. The adsorption capacities for both peels decreased in the order methyl orange $(\mathrm{MO})>$ methylene blue $(\mathrm{MB})>$ Rhodamine $\mathrm{B}(\mathrm{RB})>$ Congo red $(\mathrm{CR})>$ methyl violet $(\mathrm{MV})>$ amido black $10 \mathrm{~B}(\mathrm{AB})$. The isotherm data could be well described by the Freundlich and Langmuir equations in the concentration range of $10-120 \mathrm{mg} / \mathrm{l}$. An alkaline $\mathrm{pH}$ was favorable for the adsorption of dyes. Based on the adsorption capacity, it was shown that banana peel was more effective than orange peel. Kinetic parameters of adsorption such as the Langergren rate constant and the intraparticle diffusion rate constant were determined. For the present adsorption process intraparticle diffusion of dyes within the particle was identified to be rate limiting. Both peel wastes were shown to be promising materials for adsorption removal of dyes from aqueous solutions. () 2002 Elsevier Science B.V. All rights reserved.
\end{abstract}

Keywords: Adsorption; Dyes; Banana and orange peels; Isotherms; Kinetics

\section{Introduction}

Many industries often use dyes and pigments to color their products. Most dyes are inert and non-toxic at the concentration discharged into the receiving water, however, they impart color undesirable to the water user. Color removal from textile effluents is a major environmental problem because of the difficulty to treating such streams by conventional physicochemical and biological treatment methods [1]. Liquid-phase adsorption has been shown to be an effective way for removing suspended solids, odors, organic matter, and oil from aqueous solutions. Nassar and El-Geundi [2] evaluated the cost of dye removal

\footnotetext{
* Corresponding author. Tel.: +886-3-4636800x555; fax: +886-3-4559373.

E-mail address: cejuang@ce.yzu.edu.tw (R.-S. Juang).
} 
using natural clay, bagasse pith, and maize cob. While many physical and chemical methods including adsorption, coagulation, precipitation, filtration and oxidation have been used for the treatment of dye-containing effluent, adsorption appears to offer the best prospects over all the other treatments [3].

Activated carbon is the most widely used adsorbent for this purpose because it has a high capacity for adsorption of organic matter, but its use is limited because of its high cost [4-7]. This has led to search for cheaper substitutes. Coal, fly ash, wood, silica gel, clay materials (bentonite, montmorillonite, etc.), agricultural wastes (bagasse pith, maize cob, coconut shell, rice husk, etc.), and cotton wastes have been tried with varying success for color removal [5-9].

The purpose of this work was to test the possibility of using cellulose-based wastes, banana and orange peels, for adsorption removal of various dyes: methyl orange (MO), methylene blue (MB), Rhodamine B (RB), Congo red (CR), methyl violet (MV), and amido black 10B (AB) from water. The amounts of equilibrium adsorption were measured. The batch contact time method was used to measure the adsorption rate. Kinetic parameters were then evaluated and were finally correlated with process variables such as dye concentration and solution $\mathrm{pH}$.

\section{Materials and methods}

\subsection{Adsorbents and dyes}

Banana and orange peels were obtained from a local fruit stall at Chung-Li, Taiwan. The peels were dried, crushed, and washed thoroughly with deionized water (Milli-Q, Millipore) to remove the adhering dirt. They were air dried in an oven at $100-120^{\circ} \mathrm{C}$ for $24 \mathrm{~h}$. After drying, the adsorbent was sieved through a $5 \mathrm{~mm}$ mesh size. The densities of banana and orange peels were 1.72 and $1.47 \mathrm{~g} / \mathrm{ml}$, respectively. The BET surface areas of both peels were in the range $20.6-23.5 \mathrm{~m}^{2} / \mathrm{g}$ obtained from $\mathrm{N}_{2}$ adsorption isotherms by sorptiometer (Quantachrome Co., NOVA 2000). All dyes were obtained from Merck Co. The solution $\mathrm{pH}$ was adjusted by adding a small amount of $0.1 \mathrm{M} \mathrm{HCl}$ or $\mathrm{NaOH}$.

\subsection{Adsorption studies}

Adsorption equilibrium experiments were carried out by adding the dried adsorbent $(0.1 \mathrm{~g})$ in $100 \mathrm{ml}$ of dye solution with desired concentration and $\mathrm{pH}$ at $30^{\circ} \mathrm{C}$ in a shaker at $180 \mathrm{rpm}$. After $24 \mathrm{~h}$ the suspension was filtered and the final concentration of dye in solution was measured using an UV-VIS spectrophotometer (Hitachi U-2000). The amount of dye adsorbed onto the peels, $q_{\mathrm{e}}(\mathrm{mg} / \mathrm{g})$, was calculated by a mass balance relationship (Eq. (1)).

$$
q_{\mathrm{e}}=\left(C_{0}-C_{\mathrm{e}}\right) \frac{V}{W}
$$

where $C_{0}$ and $C_{\mathrm{e}}$ are the initial and equilibrium liquid-phase concentrations of dyes, respectively $(\mathrm{mg} / \mathrm{l}), V$ the volume of the solution $(\mathrm{L})$, and $W$ the weight of the dry peel used $(\mathrm{g})$. 
The procedures of kinetic experiments were basically identical to those of equilibrium tests. The aqueous samples were taken at preset time intervals, and the concentrations of dyes were similarly measured.

\section{Results and discussion}

\subsection{Adsorption isotherms}

Figs. 1 and 2 show the adsorption isotherms of different dyes ( $q_{\mathrm{e}}$ versus $C_{\mathrm{e}}$ ) using banana and orange peels, respectively. Two isotherm equations are tested in this work. One is the Langmuir equation (Eq. (2)), which has been successful applied to many adsorption processes [10-15].

$$
\frac{1}{q_{\mathrm{e}}}=\left(\frac{1}{q_{\mathrm{mon}}}\right)+\left(\frac{1}{K_{\mathrm{L}} q_{\mathrm{mon}}}\right)\left(\frac{1}{C_{\mathrm{e}}}\right)
$$

where $K_{\mathrm{L}}$ is the Langmuir constant and $q_{\mathrm{mon}}$ the amount of dye adsorbed when the saturation is attained. A plot of $1 / q_{\mathrm{e}}$ versus $1 / C_{\mathrm{e}}$ gives $K_{\mathrm{L}}$ and $q_{\mathrm{mon}}$ if the isotherm follows the Langmuir equation. Table 1 lists the parameters calculated. The present adsorption capacities $\left(q_{\text {mon }}\right)$ are smaller than those obtained using activated carbons, mainly because their BET surface areas are significantly different $\left(21-24 \mathrm{~m}^{2} / \mathrm{g}\right.$ versus $\left.600-1000 \mathrm{~m}^{2} / \mathrm{g}\right)[1,2]$.

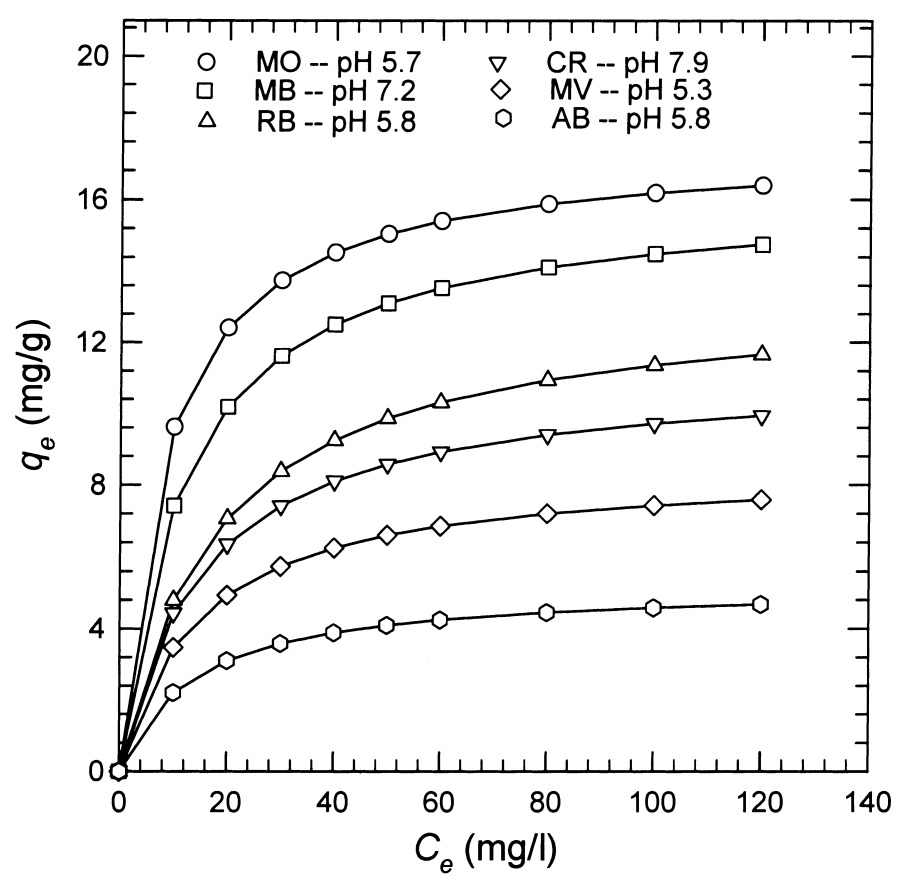

Fig. 1. Adsorption isotherms of dyes using banana peel. 


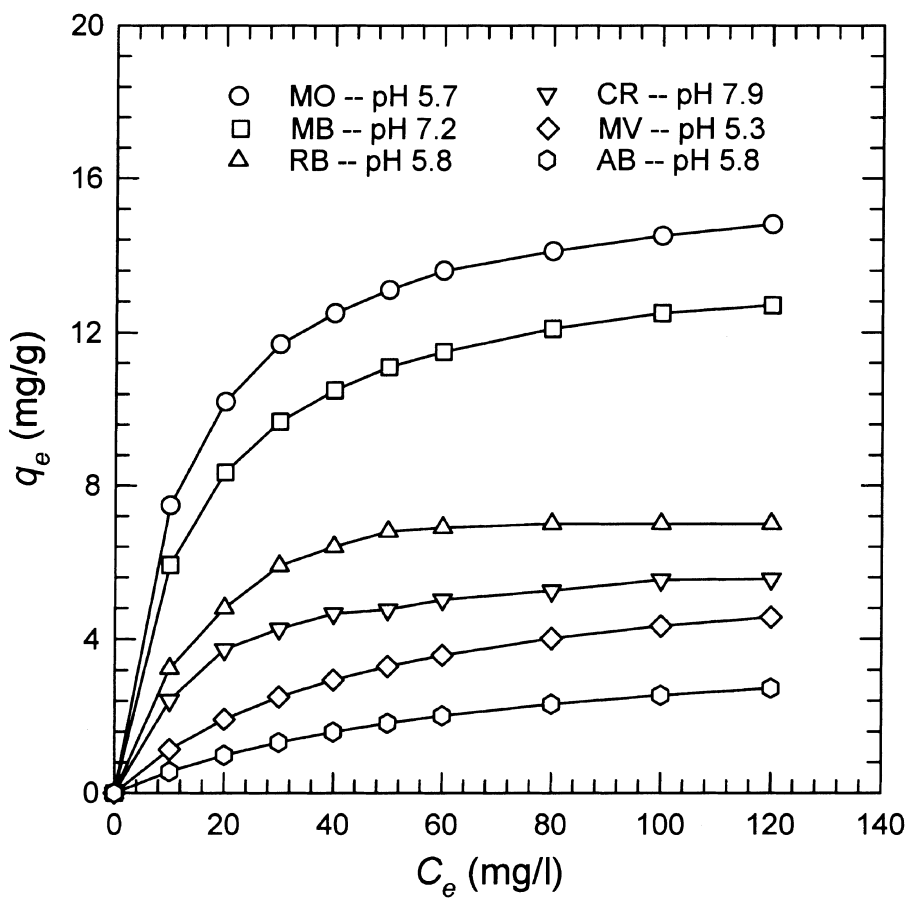

Fig. 2. Adsorption isotherms of dyes using orange peel.

The Freundlich equation [14,15], which is also often used for heterogeneous surface energy systems.

$$
\ln q_{\mathrm{e}}=\ln K_{\mathrm{F}}+\left(\frac{1}{n}\right) \ln C_{\mathrm{e}}
$$

The intercept $K_{\mathrm{F}}$ obtained from the plot of $\log q_{\mathrm{e}}$ versus $\log C_{\mathrm{e}}$ is roughly a measure of the sorption capacity and the slope $(1 / n)$ of the sorption intensity (Table 2$)$. It was indicated by that magnitude of the term $(1 / n)$ gives an indication of the favorability and capacity of the adsorbent/adsorbate systems [15].

Table 1

Parameters obtained for the Langmuir equation

\begin{tabular}{|c|c|c|c|c|c|c|}
\hline \multirow[t]{2}{*}{ Dye } & \multicolumn{3}{|l|}{ Banana peel } & \multicolumn{3}{|l|}{ Orange peel } \\
\hline & $q_{\mathrm{mon}}(\mathrm{mg} / \mathrm{g})$ & $K_{\mathrm{L}}(1 / \mathrm{mg})$ & $R$ & $q_{\text {mon }}(\mathrm{mg} / \mathrm{g})$ & $K_{\mathrm{L}}(1 / \mathrm{mg})$ & $R$ \\
\hline MO & 21.0 & 11.4 & 0.9340 & 20.5 & 16.5 & 0.9541 \\
\hline MB & 20.8 & 16.5 & 0.9524 & 18.6 & 19.9 & 0.9659 \\
\hline $\mathrm{RB}$ & 20.6 & 32.6 & 0.9572 & 14.3 & 32.0 & 0.9377 \\
\hline $\mathrm{CR}$ & 18.2 & 37.7 & 0.9480 & 14.0 & 46.8 & 0.9739 \\
\hline MV & 12.2 & 29.1 & 0.9616 & 11.5 & 56.7 & 0.9794 \\
\hline $\mathrm{AB}$ & 6.5 & 17.4 & 0.9632 & 7.9 & 59.2 & 0.9747 \\
\hline
\end{tabular}


Table 2

Parameters obtained for the Freundlich equation ${ }^{\mathrm{a}}$

\begin{tabular}{|c|c|c|c|c|c|c|}
\hline \multirow[t]{2}{*}{ Dye } & \multicolumn{3}{|c|}{ Banana peel } & \multicolumn{3}{|c|}{ Orange peel } \\
\hline & $K_{\mathrm{F}}$ & $1 / n$ & $R$ & $K_{\mathrm{F}}$ & $1 / n$ & $R$ \\
\hline MO & 1.73 & 0.26 & 0.9861 & 2.20 & 0.17 & 0.9401 \\
\hline MB & 1.34 & 0.33 & 0.9851 & 1.75 & 0.26 & 0.9519 \\
\hline $\mathrm{RB}$ & 0.39 & 0.47 & 0.9644 & 1.01 & 0.39 & 0.9399 \\
\hline $\mathrm{CR}$ & 0.05 & 0.54 & 0.9589 & 0.65 & 0.44 & 0.9820 \\
\hline MV & 1.08 & 0.73 & 0.9867 & 0.24 & 0.59 & 0.9566 \\
\hline $\mathrm{AB}$ & 1.26 & 0.66 & 0.9687 & 0.65 & 0.99 & 0.9470 \\
\hline
\end{tabular}

${ }^{\text {a }}$ Unit of $K_{\mathrm{F}}$ was $(\mathrm{mg} / \mathrm{g})(\mathrm{mg} / \mathrm{l})^{n}$.

Based on the correlation coefficient $(R)$ shown in Tables 1 and 2, the adsorption isotherms with banana peel can be slightly better described by the Freundlich equation, and by the Langmuir equation in the case of organic peel. The fit of the data to the Freundlich equation may indicate the heterogeneity of the adsorbent surface.

\subsection{Effect of solution $\mathrm{pH}$ on adsorption capacity}

The effect of solution $\mathrm{pH}$ on the adsorption of dyes by banana and orange peels was shown in Figs. 3 and 4. For banana peel, the amount of adsorption increases when the $\mathrm{pH}$

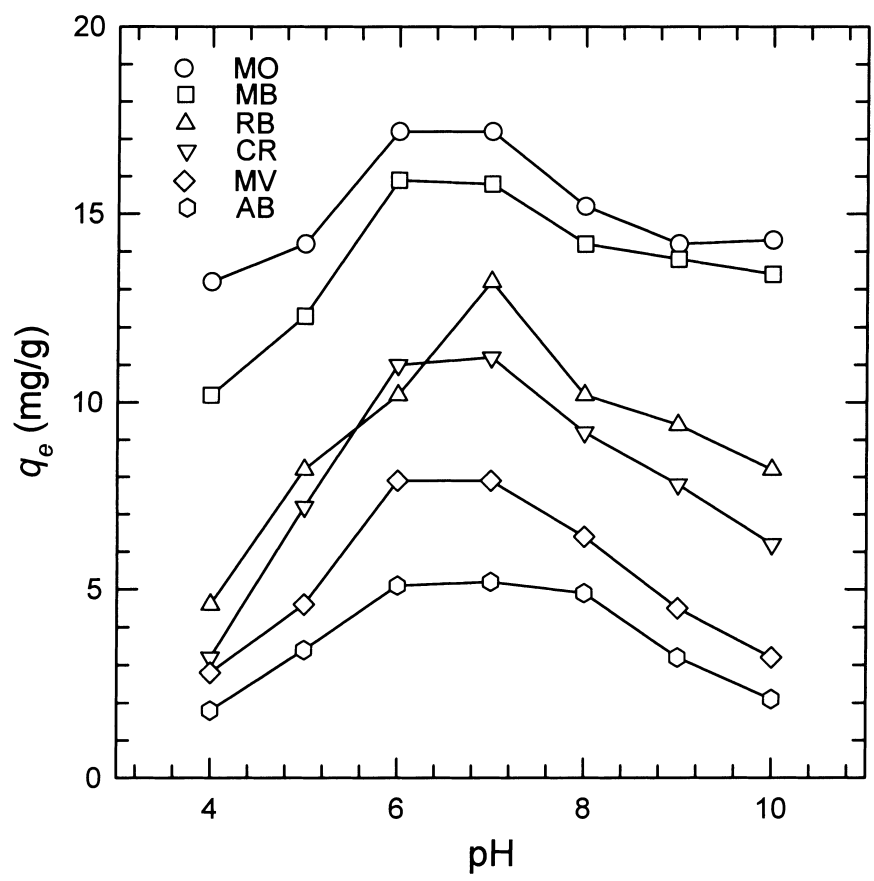

Fig. 3. Effect of $\mathrm{pH}$ on adsorption of dyes using banana peel $\left(C_{0}=100 \mathrm{mg} / \mathrm{l}\right)$. 


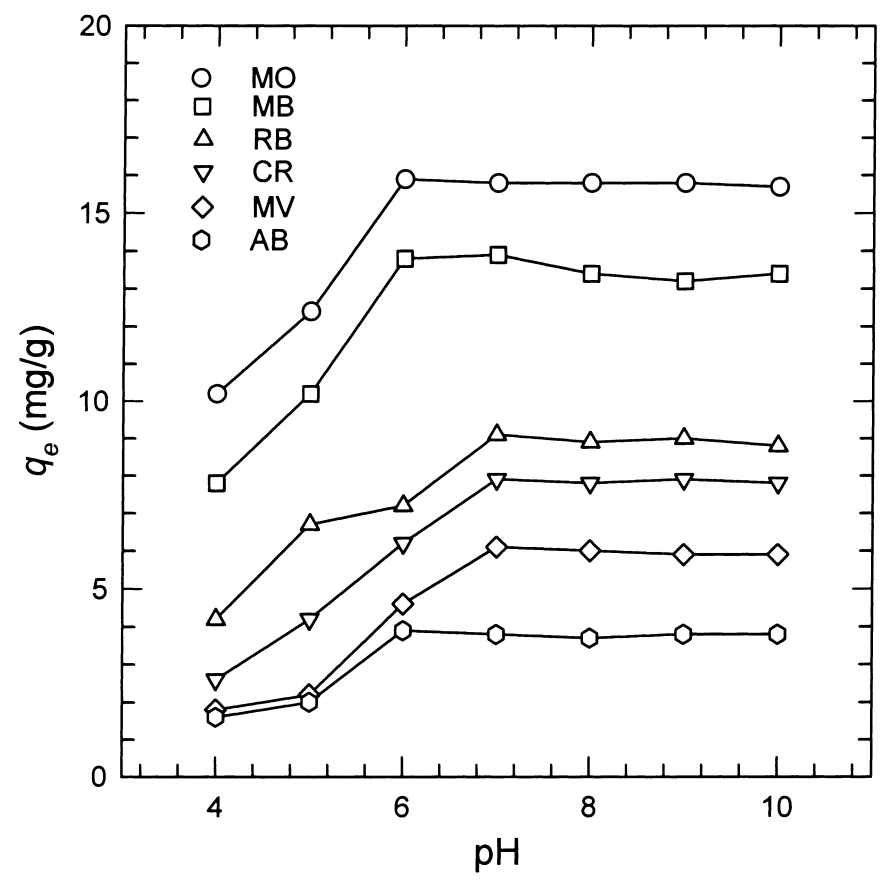

Fig. 4. Effect of $\mathrm{pH}$ on adsorption of dyes using orange peel $\left(C_{0}=100 \mathrm{mg} / \mathrm{l}\right)$

is increased. The adsorption capability reaches maximum at $\mathrm{pH} 6-7$, but decreases when $\mathrm{pH}$ is increased further. Similar results of $\mathrm{pH}$ effect were also reported for the adsorption of dyes on banana peel [16] and biological waste slurry [17], and even of $\mathrm{Ni}^{2+}$ on orange peel [18]. In the case of orange peel (Fig. 4), however, the amount of dye adsorbed reaches a plateau at $\mathrm{pH}>7$. Under the conditions tested in Figs. 3 and 4, the highest amounts of adsorption are 17.2 (MO), 15.9 (MB), $13.2(\mathrm{RB}), 11.2(\mathrm{CR}), 7.9(\mathrm{MV})$, and 7.9 (AB) mg/g using banana peel, as well as $15.8(\mathrm{MO}), 13.9(\mathrm{MB}), 9.1(\mathrm{RB}), 7.9(\mathrm{CR}), 6.1(\mathrm{MV})$, and $-3.8(\mathrm{AB}) \mathrm{mg} / \mathrm{g}$ using orange peel.

Solution $\mathrm{pH}$ would affect both aqueous chemistry and surface binding-sites of the adsorbents. At lower $\mathrm{pH}, \mathrm{H}^{+}$may compete with dye ions for the adsorption sites of both peel wastes, thereby inhibiting the adsorption of dyes. Actually, the zeta potentials of the adsorbent suspensions were measured (Malvern Zetasizer 3000 system). From pH 2.0 to 8.0 , the zeta potentials of original banana and orange peels decline from -8.2 to $-62.4 \mathrm{mV}$ and from -3.2 to $-44.5 \mathrm{mV}$, respectively (not shown). The sharper change in zeta potential for banana peel than orange peel may explain their different $\mathrm{pH}$ trends of dye adsorption.

The SEM images of original banana and orange peels (Fig. 5a and b) show that the pores within the peel particles are highly heterogeneous. However, this is not the case after adsorption (Fig. 5c and d). After dye adsorption, a significant change is observed in structure of the peels. The peels appear to have a rough surface with crater-like pores because they are partially covered by dye molecules. 


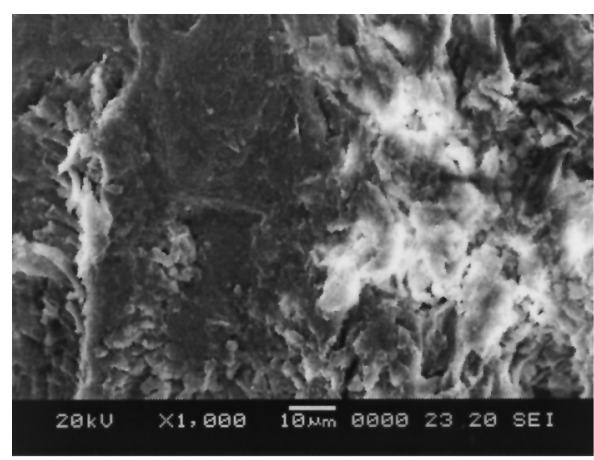

(a)

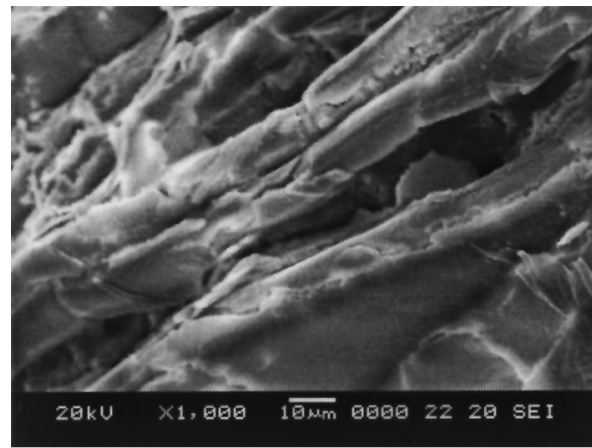

(c)

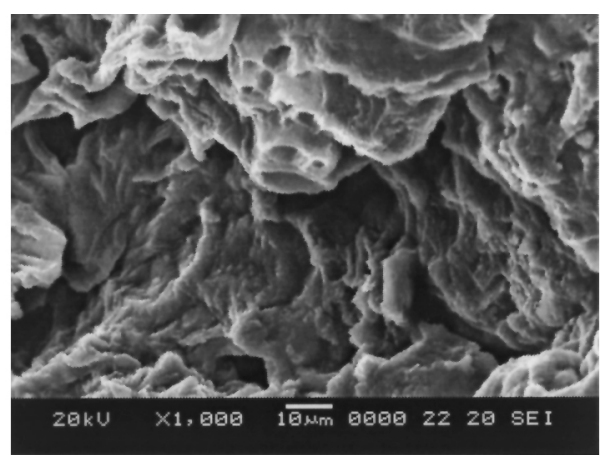

(b)

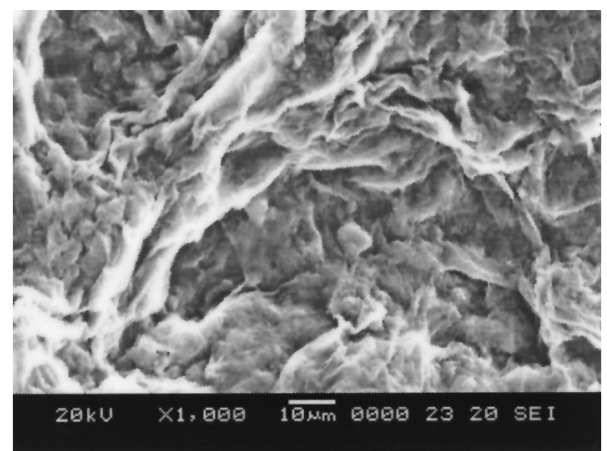

(d)

Fig. 5. SEM images for banana and orange peels: (a) original banana peel; (b) original orange peel; (c) banana peel after adsorption and (d) orange peel after adsorption.

\subsection{Adsorption kinetics}

Figs. 6 and 7 show that the amount of dye adsorption increases with time and it remains constant after a contact time of about $65 \mathrm{~min}$ (i.e. the equilibrium time). The equilibrium time is independent of initial dye concentration. The time profile of dye uptake is a single, smooth, and continuous curve leading to saturation, suggesting the possible monolayer coverage of dyes on the surface of the adsorbent. The Langergren equation, a pseudo-first-order equation, describes the kinetics of adsorption process as follows [4,19].

$$
\log \left(q_{\mathrm{e}}-q_{t}\right)=\log q_{\mathrm{e}}-\left(\frac{k_{1}}{2.303}\right) t
$$

where $q_{t}$ is the amount of dye adsorbed $(\mathrm{mg} / \mathrm{g})$ at any time, and $k_{1}$ is the rate constant. The plot of $\log \left(q_{\mathrm{e}}-q_{t}\right)$ versus $t$ indicates that such first-order rate expression is not so valid to the present systems (not shown, correlation coefficient $<0.91$ ). However, the values of $k_{1}$ calculated are still listed in Table 3 for reference. 


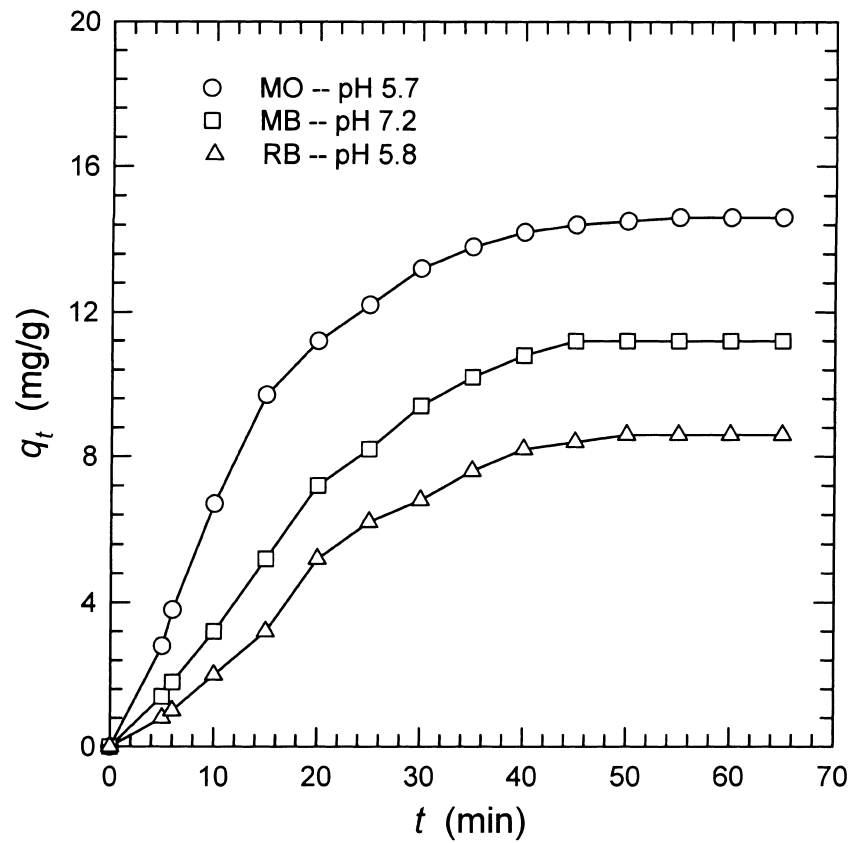

Fig. 6. Time profiles of solid-phase concentrations of dyes using banana peel $\left(C_{0}=50 \mathrm{mg} / \mathrm{l}\right)$.

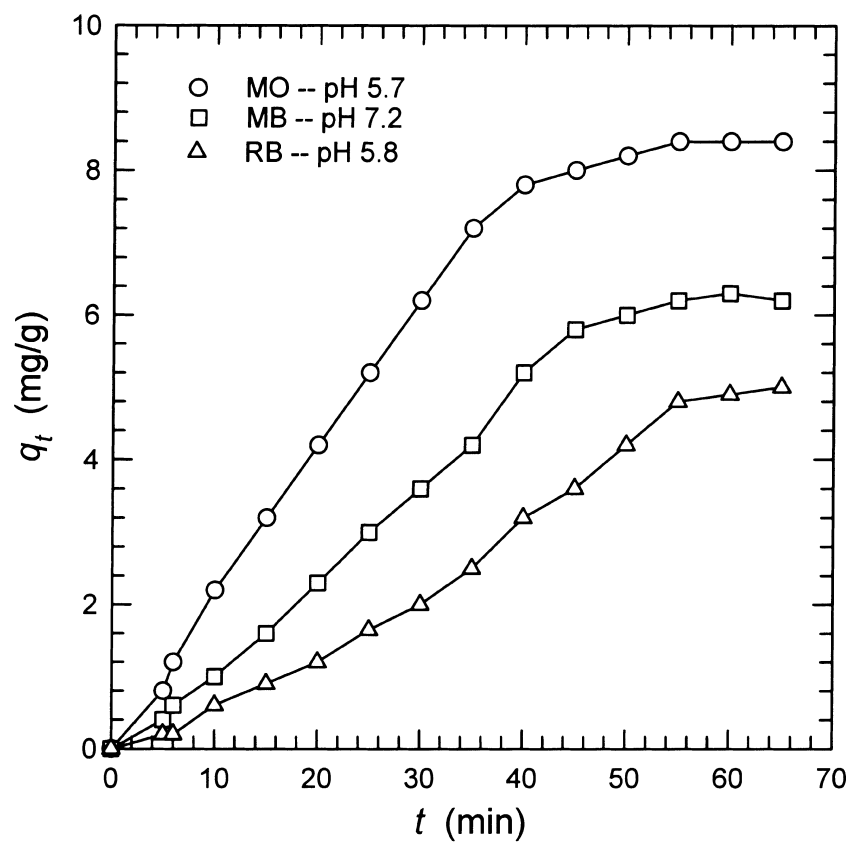

Fig. 7. Time profiles of solid-phase concentrations of dyes using orange peel $\left(C_{0}=50 \mathrm{mg} / \mathrm{l}\right)$. 
Table 3

Parameters obtained for different dyes

\begin{tabular}{llllll}
\hline Dye & \multicolumn{2}{l}{ Banana peel } & & \multicolumn{2}{l}{ Orange peel } \\
\cline { 2 - 3 } \cline { 5 - 6 } & $k_{1}\left(\mathrm{~min}^{-1}\right)$ & $k_{\mathrm{p}}\left(\mathrm{mg} /\left(\mathrm{g} \mathrm{min}{ }^{1 / 2}\right)\right)$ & & $k_{1}\left(\mathrm{~min}^{-1}\right)$ & $k_{\mathrm{p}}\left(\mathrm{mg} /\left(\mathrm{g} \mathrm{min}{ }^{1 / 2}\right)\right)$ \\
\hline MO & 0.39 & 2.42 & 0.40 & 1.68 \\
MB & 0.35 & 2.12 & 0.29 & 1.20 \\
RB & 0.19 & 1.70 & 0.21 & 0.81 \\
\hline
\end{tabular}

The data of solid-phase dye concentrations against time at an initial dye concentration of $20 \mathrm{mg} / \mathrm{l}$ were further processed for testing the role of diffusion (as the rate controlling step) in the adsorption process. Adsorption process incorporates the transport of adsorbate from bulk solution to the interior surface of the pores [20]. There is a possibility that the transport of dyes from the solution into the pores of the adsorbent is rate controlling in batch experiments with rapid stirring. The rate parameters for intraparticle diffusion $\left(k_{\mathrm{p}}\right)$ for different dyes are determined using the following equation [21].

$$
q_{t}=k_{\mathrm{p}} t^{1 / 2}
$$

where $k_{\mathrm{p}}$ is the intraparticle diffusion rate constant.

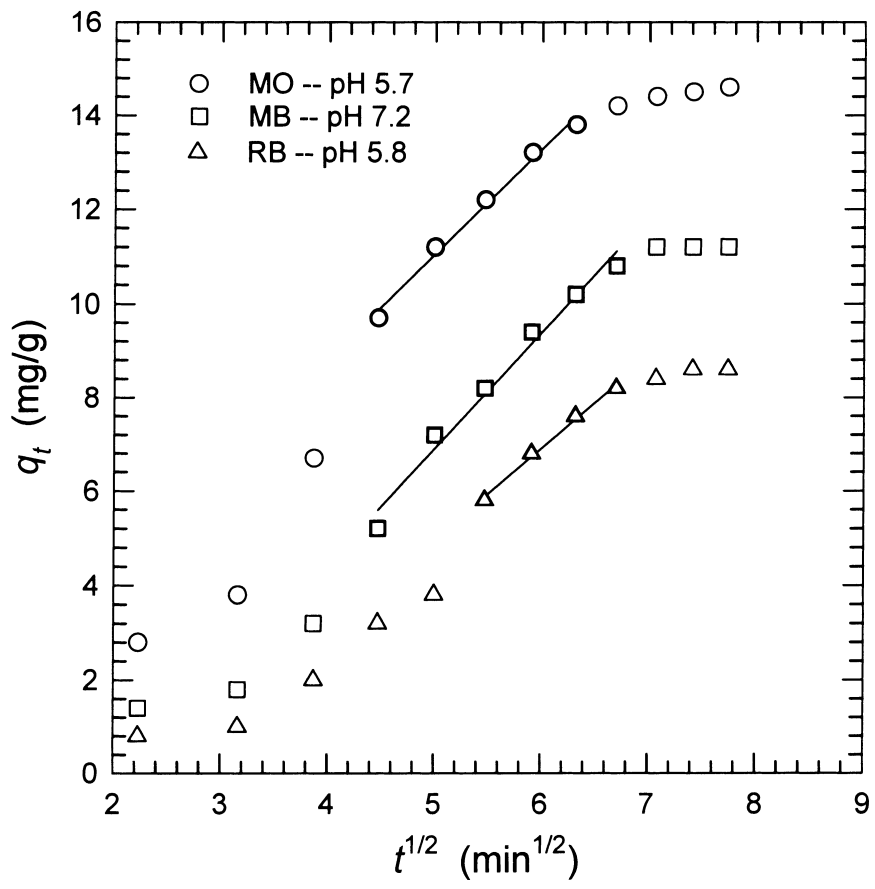

Fig. 8. Test of intraparticle diffusion model for adsorption of dyes using banana peel. 


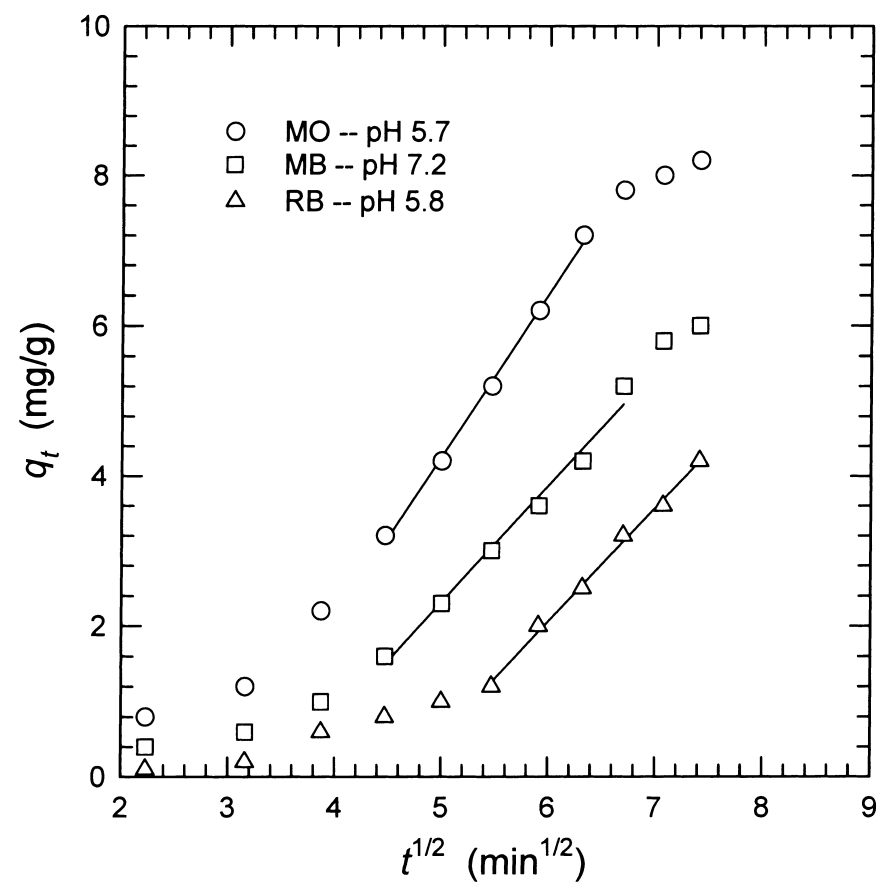

Fig. 9. Test of intraparticle diffusion model for adsorption of dyes using orange peel.

Due to mass transfer effects, the shape of $q_{t}$ versus $t^{1 / 2}$ plot is curved at a small time limit [20]. All the plots have the same general features, initial curved portion followed by linear portion and a plateau. The initial curved portion is attributed to the bulk diffusion and the linear portion to the intraparticle diffusion. These phenomena have been reported for the adsorption of $\mathrm{Cd}^{2+}$ on waste $\mathrm{Fe}(\mathrm{III}) / \mathrm{Cr}$ (III) hydroxide [22] and on thermally activated electroplating sludge [23]. At a certain time limit (about $20 \mathrm{~min}$ ), the curves reveal a linear characteristic that the intraparticle diffusion controls the adsorption process (Figs. 8 and 9). The values of $k_{\mathrm{p}}$ are obtained from the slope of the straight lines, and are listed in Table 3. According to the acceptable adsorption capacity (based on per specific surface area) and rate, the present low-cost peel wastes are expected to be attractive for adsorption removal of color from aqueous streams. Unlike activated carbons, however, thermal regeneration of the peel wastes is not feasible. Thus, the spent adsorbents may be post-treated with other solid wastes such as activated sludge.

\section{Conclusion}

Equilibrium and kinetic studies were made for the adsorption of dyes from aqueous solutions onto banana and orange peels in the concentration range $10-120 \mathrm{mg} / \mathrm{l}$ at $30^{\circ} \mathrm{C}$. The Freundlich equation showed a somewhat better fit than does the Langmuir equation for 
adsorption of dyes using banana peel, but exactly reversed using orange peels. Under the conditions tested $\left(C_{0}=100 \mathrm{mg} / \mathrm{l}\right.$, dosage of adsorbent $\left.1 \mathrm{~g} / \mathrm{l}\right)$, the amounts of adsorption were maximized at pH 6-7 up to $17.2(\mathrm{MO}), 15.9(\mathrm{MB}), 13.2(\mathrm{RB}), 11.2(\mathrm{CR}), 7.9(\mathrm{MV})$, and $7.9(\mathrm{AB}) \mathrm{mg} / \mathrm{g}$ using banana peel, and at $\mathrm{pH}>7$ up to $15.8(\mathrm{MO}), 13.9(\mathrm{MB}), 9.1(\mathrm{RB})$, $7.9(\mathrm{CR}), 6.1(\mathrm{MV})$, and $-3.8(\mathrm{AB}) \mathrm{mg} / \mathrm{g}$ using orange peel. The intraparticle diffusion of dye molecules within the particles was found to be rate controlling in these adsorption processes after $20 \mathrm{~min}$ contact. The present work revealed that the waste banana and orange peels were the promising materials for the removal of dyes from aqueous solutions.

\section{Acknowledgements}

Financial support for this work by the National Science Council, ROC, under Grant NSC 89-2211-E-002-008, is gratefully appreciated.

\section{References}

[1] G. McKay, Adsorption of dyestuffs from aqueous solutions with activated carbon. Part I. Equilibrium and batch contact-time studies, J. Chem. Technol. Biotechnol. 32 (1982) 759-772.

[2] M.M. Nassar, M.S. El-Geundi, Comparative cost of color removal from textile effluents using natural adsorbents, J. Chem. Technol. Biotechnol. 50 (1991) 257-264.

[3] P. Nigam, I.M. Banat, D. Singh, R. Marchant, Microbial process for decolorization of textile effluent containing azo, diazo and reactive dyes, Process Biochem. 31 (1996) 435-442.

[4] A.K. Battacharya, C. Venkobachar, Removal of cadmium(II) by low cost adsorbents, J. Environ. Eng. ASCE 110 (1984) 110-122.

[5] B.K. Singh, N.S. Rawat, Comparative sorption equilibrium studies of toxic phenols on fly ash and impregnated fly ash, J. Chem. Technol. Biotechnol. 61 (1994) 307-317.

[6] G. McKay, G.R. Prasad, P.R. Mowli, Equilibrium studies for the adsorption of dyestuffs from aqueous solutions by low-cost materials, Water Air Soil Pollut. 29 (1986) 273-283.

[7] S.K. Khare, K.K. Panday, R.M. Srivastava, V.N. Singh, Removal of victoria blue from aqueous solution by fly ash, J. Chem. Technol. Biotechnol. 38 (1987) 99-104.

[8] R.S. Juang, F.C. Wu, R.L. Tseng, The ability of activated clay for the adsorption of dyes from aqueous solutions, Environ. Technol. 18 (1997) 525-531.

[9] B.K.G. Theng, N. Wells, Assessing the capacity of some New Zealand clays for decolourizing vegetable oil and butter, Appl. Clay. Sci. 9 (1995) 321-326.

[10] M.S. El-Geundi, Color removal from textile effluents by adsorption techniques, Water Res. 25 (1991) 271273.

[11] M.S. El-Geundi, Pore diffusion model for the adsorption of basic dyestuffs onto natural clay in batch adsorbers, Adsorp. Sci. Technol. 11 (1994) 109-120.

[12] G. Annadurai, M. Chellapandian, M.R.V. Krishnan, Adsorption of reactive dye on chitin, Environ. Monitor. Assess. 59 (1999) 111-119.

[13] X. Zhao, K. Urano, S. Ogasawara, Adsorption of polyethylene glycol from aqueous solution on montmorillonite clays, Colloid Polym. Sci. 267 (1989) 899-906.

[14] J.A. Stephen, G. McKay, K.Y.H. Khader, Equilibrium adsorption isotherms for basic dyes onto lignite, J. Chem. Technol. Biotechnol. 45 (1989) 29-32.

[15] V.J.P. Poots, G. McKay, J.J. Healy, Removal of basic dye from effluent using wood as an adsorbent, Water Pollut. Cont. Fed. 50 (1978) 926-935.

[16] C. Namasivayam, N. Muniyasamy, K. Gayatri, M. Rani, K. Renganathan, Removal of dyes from aqueous solutions by cellulose waste orange peel, Biores. Technol. 57 (1996) 37-43. 
[17] R.T. Yammuna, C. Namasivayam, Color removal from aqueous solution by biogas residual slurry, Toxicol. Environ. Chem. 38 (1993) 131-143.

[18] M. Ajmal, R.A.K. Rao, R.J.A. Ahmad, Adsorption studies on Citrus reticulata: removal and recovery of $\mathrm{Ni}(\mathrm{II})$ from electroplating wastewater, J. Hazard. Mater. B79 (2000) 117-131.

[19] C. Namasivayam, K. Renganathan, Removal of Cd(II) from waste water by adsorption on $\mathrm{Fe}(\mathrm{III}) / \mathrm{Cr}$ (III) hydroxide, Water Res. 29 (1995) 1737-1744.

[20] B.K. Singh, N.S. Rawat, Comparative sorption kinetic studies of phenolic compounds on fly ash and impregnated fly ash, J. Chem. Technol. Biotechnol. 61 (1994) 57-65.

[21] W.J. Weber, J.C. Morris, Kinetics of adsorption on carbon solution, J. San. Eng. Div. ASCE 89 (1963) 31-59.

[22] C. Namasivayam, K. Renganathan, Waste $\mathrm{Fe}(\mathrm{III}) / \mathrm{Cr}(\mathrm{III})$ hydroxide as adsorbent for removal of $\mathrm{Cr}(\mathrm{VI})$ from aqueous solution and chromium plating industrial wastewater, Environ. Pollut. 82 (1993) 255-261.

[23] R.Y. Stefanova, Sorption of metal ions from aqueous solutions by the thermally activated electroplating sludge, J. Environ. Sci. Health A35 (2000) 593-607. 